\title{
Granular Cell Tumor Located in the Bulbar Subconjunctival Space
}

\author{
Eduardo F. Marback Eduardo Studart Luciano Espinheira Fonseca Jr.
}

Roberto L. Marback

Federal University of Bahia, Salvador, Brazil

\section{Established Facts}

- Granular cell tumor is a rare tumor that can occur in the tarsal conjunctiva.

\section{Novel Insights}

- Granular cell tumors do occur in the bulbar conjunctiva.

\section{Keywords}

Granular cell tumor - Conjunctiva · Conjunctival tumor · Abrikossoff tumor

\begin{abstract}
Aim: To report an unusual case of granular cell tumor. Methods: Case report. Results: A 14-year-old male presented with a bulbar conjunctival yellowish nonmovable mass, in the left eye. The tumor was removed and histopathologic evaluation revealed a granular cell tumor. Conclusion: Granular cell tumor can occur at the bulbar subconjunctival space.

(c) 2017 S. Karger AG, Basel
\end{abstract}

\section{Introduction}

Granular cell tumor (GCT) was first described in the tongue and, at that moment, supposed to originate from mature striated muscle cells [1]. Immunohistochemistry and ultrastructural studies have identified GCT to originate from Schwann cells $[2,3]$. A review by Ordóñez and Mackay [4] concluded that GCT is most frequently located in the head and neck area. About one-fourth of the lesions occurred in the tongue. Other reported sites are the orbit, larynx, parotids, breast, esophagus, respiratory, gastrointestinal, and genitourinary tracts [4].

In ocular adnexa, GCT has been reported to occur in the orbit, extraocular muscles, caruncule, eyelid skin, palpebral conjunctiva, and lacrimal drainage apparatus [512]. In our literature search, no clear report of GCT isolated in the bulbar subconjunctival space was found.

\section{KARGER}

(C) 2017 S. Karger AG, Basel

E-Mail karger@karger.com

www.karger.com/oop
Eduardo F. Marback

Federal University of Bahia

Rua Eduardo José dos Santos, 147, Sala 808

Salvador, Bahia 41940-455 (Brazil)

E-Mail eduardomarback@uol.com.br 

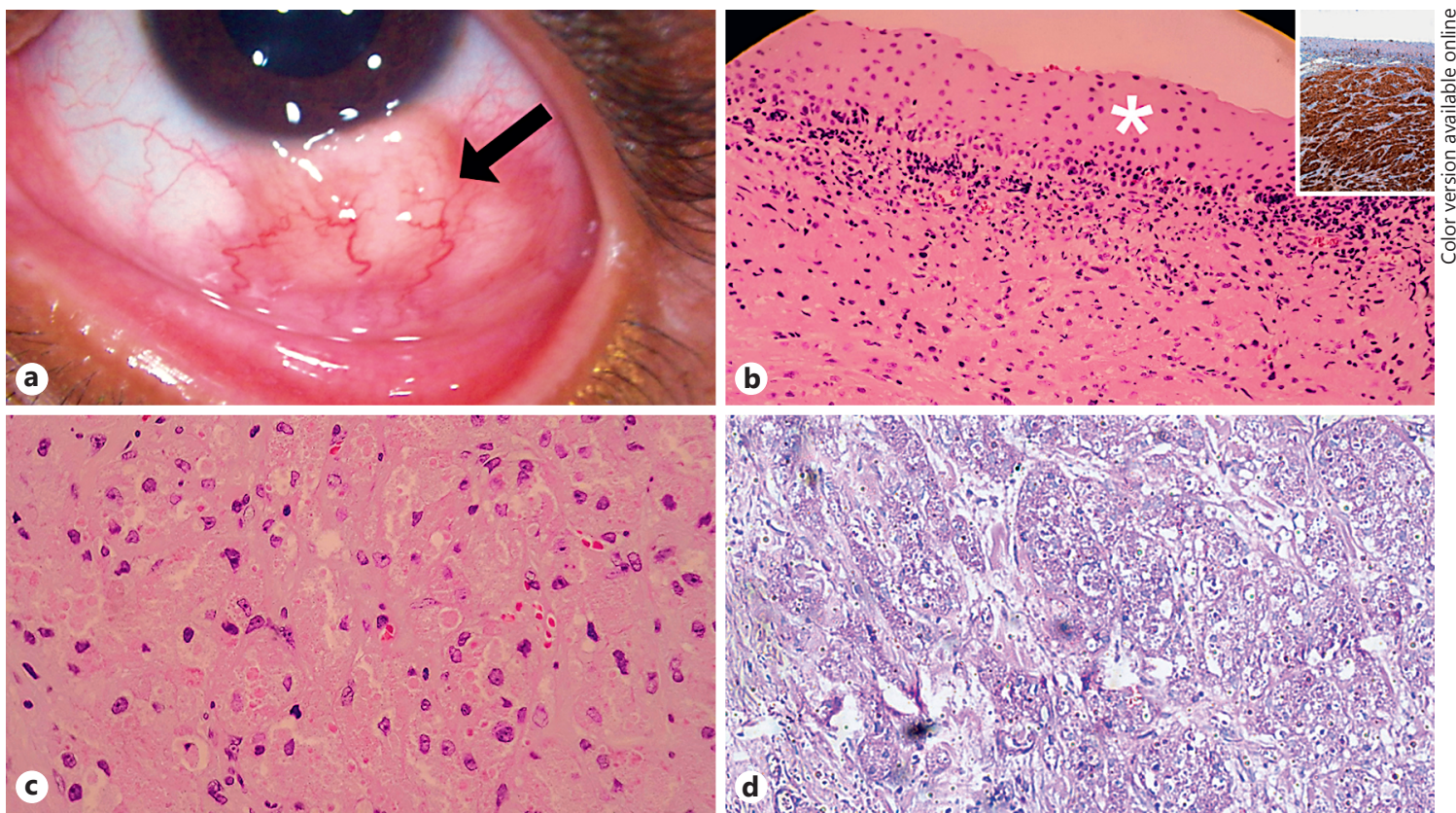

Fig. 1. a Clinical aspect. A yellowish mass in the temporal area from the bulbar conjunctiva (arrow). b Microphotography. At lower magnification, tumor cells can be identified under a normal conjunctival epithelium (asterisk) (H\&E, ×200). Inset Strong S-100 positivity. c Microphotography. At higher magnification, the cells exhibit small round nuclei and granular eosinophilic cytoplasm $(\mathrm{H} \& \mathrm{E}, \times 400)$. d Microphotography. PAS-positive cytoplasm granules (PAS, $\times 400)$.

\section{Case Report}

A 14-year-old male was referred for ocular oncology evaluation. He reported a progressively growing mass in the left eye for the last 5 months. There were no other ocular or systemic complaints. His past medical history was unremarkable.

Ocular examination revealed a $10 \times 6 \mathrm{~mm}$ lobulated yellowish mass occupying the inferior and lateral portion of the left subconjunctival space (Fig. 1). Although the conjunctiva over the mass was brilliant and apparently undisturbed, it could not be moved over the tumor, which in turn seemed to be firmly attached to the episclera. Surgical excision was performed with superficial lamellar sclerectomy and primary wound closure with interrupted 8-0 polyglactin suture. The patient was prescribed with tobramycin eye drops for 7 days and $0.1 \%$ dexamethasone eye drops tapered over a 30-day period. Visual acuity remained normal and there was no other visual limitation. At the 12-month follow-up visit, there was no evidence of local recurrence.

Histopathological evaluation revealed a preserved conjunctival epithelium and a tumor in the subconjunctival space, composed of benign cells exhibiting small round nuclei and granular eosinophilic cytoplasm. The cytoplasmic granules were periodic acidSchiff (PAS) positive and exhibited positive immunostaining for S-100 and CD-68 (Fig. 1).

Subconjunctival Granular Cell Tumor

\section{Comments}

GCT is a rare tumor that usually presents in the 4 th to 6 th decade with no gender predilection $[5,7]$. Although it has been reported to affect many structures of the ocular adnexa, including the palpebral conjunctiva, we found no single case located at the subconjunctival bulbar space [5-12].

The tumor is usually benign, but complete excision is advised since local invasion after incomplete excision has been reported to result in orbital exenteration [12]. Complete excision can be challenging since this tumor is known to be usually firmly adherent to deeper planes [57]. In our case, the tumor was adherent to the superficial episcleral tissue, but complete excision was performed with superficial lamellar sclerectomy.

The diagnosis of GCT is usually made on the basis of its typical features on light microscopy hematoxylin and eosin-stained and PAS sections (small round nuclei and granular cytoplasm that are PAS positive) $[4,8]$. Due to its neural origin, the tumor frequently stains positive for S-100 protein and neuron-specific enolase $[2-4,8]$. Another marker that frequently stains positive in GCT is 
CD-68. This was once interpreted as a possible histiocytic origin for GCT, but lately, CD-68 positivity was proved to be a common finding in a variety of lesions rich in lysosomes, thus making this immunomarker not a specific one to GCT $[2-4,8]$.

In this unusual location, GCT can mimic many other rare stromal conjunctival lesions and a correct clinical diagnosis is virtually impossible, making surgical excision with histopathological study mandatory. Another aspect reported in GCT that could induce clinical and even histopathological confusion is the presence of pseudoepitheliomatous hyperplasia. This finding was already reported in cases of palpebral conjunctival GCT, but was not identified in the present case [10].

In summary, we present a rare case of GCT located in the bulbar subconjunctival space. We highlight the tu- mor's clinical, surgical, and histopathological aspects and comment on the challenges to diagnose and surgically manage such a lesion.

\section{Statement of Ethics}

The subject has given prior informed consent for the treatment and for publication of this paper.

\section{Disclosure Statement}

None of the authors have any sponsorship or funding arrangements relating to this paper. None of the authors have any possible conflicts of interest related to this paper.

\section{References}

1 Abrikossoff A: Über Myome, ausgehend von der quergestreiften willkürlichen Muskulatur. Virchows Arch Path Anat Physiol 1926; 260:215-233.

2 Fisher ER, Wechsler H: Granular cell myoblastoma - a misnomer. Electron microscopic and histochemical evidence concerning its Schwann cell derivation and nature (granular cell schwannoma). Cancer 1962;15:936-954.

3 Mazur MT, Shultz JJ, Myers JL: Granular cell tumor. Immunohistochemical analysis of 21 benign and one malignant tumor. Arch Pathol Lab Med 1990;114:692-696.
4 Ordóñez NG, Mackay B: Granular cell tumor: a review of the pathology and histogenesis. Ultrastruct Pathol 1999;23:207-222.

5 Jaeger MJ, Green WR, Miller NR, et al: Granular cell tumor of the orbit and ocular adnexae. Surv Ophthalmol 1987;31:417-423.

6 Fernandes BF, Belfort Neto R, Odashiro AN, et al: Clinical and histopathological features of orbital granular cell tumor: case report. Arq Bras Oftalmol 2012;75:137-139.

7 Ribeiro SF, Chahud F, Cruz AA: Oculomotor disturbances due to granular cell tumor. Ophthal Plast Reconstr Surg 2012;28:e23-e27.

8 Evans M, Chang E, Yu DL, Rao NA: Granular cell tumour: a rare caruncle lesion. $\mathrm{Br} J \mathrm{Oph}-$ thalmol 2006;90:246-247.
9 Scruggs RT, Black EH: Granular cell tumor masquerading as a chalazion: a case report. Ophthal Plast Reconstr Surg 2015;31:e6-e8.

10 Ferry AP: Granular cell tumor (myoblastoma) of the palpebral conjunctiva causing pseudoepitheliomatous hyperplasia of the conjunctival epithelium. Am J Ophthalmol 1981;91:234-238.

11 Sabet SJ, Tarbet KJ, Lemke BN, Smith ME, Albert DM: Granular cell tumor of the lacrimal sac and nasolacrimal duct: no invasive behavior with incomplete resection. Ophthalmology 2000;107:1992-1994.

12 Salour H, Tavakoli M, Karimi S, Rezaei Kanavi M, Faghihi M: Granular cell tumor of the orbit. J Ophthalmic Vis Res 2013;8:376-379. 